\title{
New HIF2 $\alpha$ inhibitors: potential implications as therapeutics for advanced pheochromocytomas and paragangliomas
}

\section{Rodrigo Almeida Toledo*}

Division of Hematology and Medical Oncology, Department of Medicine, Cancer Therapy and Research Center, University of Texas Health Science Center at San Antonio (UTHSCSA), San Antonio, Texas, USA *(R A Toledo is now at Vall d'Hebron Institute of Oncology (VHIO), Centro Cellex, Calle Natzaret, Barcelona, Spain)
Correspondence should be addressed to $\mathrm{R}$ A Toledo

Email

toledorodrigo79@gmail.com

\begin{abstract}
Two recent independent studies published in Nature show robust responses of clear cell renal cell carcinoma ( $c C R C C)$ cell lines, preclinical ccRCC xenograft models and, remarkably, a patient with progressive cCRCC despite receiving multiple lines of treatment, to the long-awaited, recently developed inhibitors of hypoxia-inducible factor 2-alpha (HIF2 $\alpha$ ). This commentary published in Endocrine-Related Cancer is based on the recognition of similar molecular drivers in $\mathrm{CRCC}$ and the endocrine neoplasias pheochromocytomas and paragangliomas (PPGLs), ultimately leading to stabilization of HIFs. HIF-stabilizing mutations have been detected in the von Hippel-Lindau (VHL) gene, as well as in other genes, such as succinate dehydrogenase (SDHx), fumarate hydratase $(\mathrm{FH})$ and transcription elongation factor $\mathrm{B}$ subunit 1 (TCEB1), as well as the gene that encodes HIF2 $\alpha$ itself: EPAS1HF2 $\alpha$. Importantly, the recent discovery of EPAS1 mutations in PPGLs and the results of comprehensive in vitro and in vivo studies revealing their oncogenic roles characterized a hitherto unknown direct mechanism of HIF2 $\alpha$ activation in human cancer. The now available therapeutic opportunity to successfully inhibit HIF $\alpha$ pharmacologically with PT2385 and PT2399 will certainly spearhead a series of investigations in several types of cancers, including patients with SDHB-related metastatic PPGL for whom limited therapeutic options are currently available. Future studies will determine the efficacy of these promising drugs against the hotspot EPAS1 mutations affecting HIF2 $\alpha$ amino acids 529-532 (in PPGLs) and amino acids 533-540 (in erythrocytosis type 4), as well as against HIF2 $\alpha$ protein activated by $V H L, S D H x$ and $F H$ mutations in PPGL-derived chromatin cells.
\end{abstract}

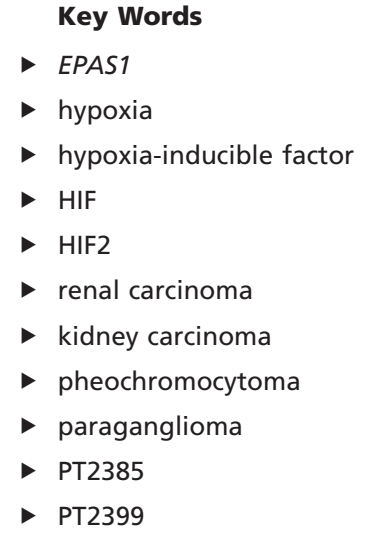

Endocrine-Related Cancer (2017) 24, C9-C19

\section{Tumor hypoxia and anti-angiogenesis cancer therapy}

The molecular mechanisms used by cells to adapt and respond to hypoxia have mainly been elucidated in a series of elegant studies conducted by Gregg L Semenza
(Johns Hopkins University School of Medicine, Baltimore, Maryland), William G Kaelin (Harvard Medical School, Boston, Massachusetts, USA) and Peter J Ratcliffe 
(University of Oxford, London, United Kingdom). These researchers were awarded the 2016 Albert Lasker Basic Medical Research Award for these fundamental contributions (Kaelin et al. 2016).

In physiological hypoxia, the molecular pathways controlled by hypoxia-inducible factors (HIFs) cooperate to restore tissue homeostasis. In contrast, the same molecular pathways are hijacked by cancer cells localized in hypoxic tumor regions that are generated during rapid oncogenic clonal expansion (revised by Bertout et al. 2008, Kaelin 2008). Tumor progression depends on neo-angiogenesis through the secretion of vascular endothelial growth factor A (VEGFA). The process of tumor neo-angiogenesis was initially described by Moses Judah Folkman (1936-2008) at the beginning of the 1970s, and has since been investigated extensively (Folkman 1971, 1995, 2007, Weidner et al. 1991, Hanahan et al. 1996). Neo-angiogenesis is currently considered a hallmark of cancers (Hanahan \& Weinberg 2011) and is briefly illustrated below. (a) the HIF2 $\alpha$-target VEGFA gene is de novo transcribed in hypoxic (or pseudohypoxic, see below) cancer cells. (b) The translated VEGFA ligand is secreted and then binds and activates type-2 VEGF receptors (VEGFR2) expressed on the membranes of endothelial cells surrounding the tumor, stimulating the sprouting of blood vessels toward the tumor. (c) Cancer cells then gain access to greater amounts of nutrients and oxygen, sustaining and enhancing tumorigenesis (Bertout et al. 2008, Kaelin 2008). With a better understanding of this mechanism, the development of a new category of cancer drugs capable of impeding neo-angiogenesis with the aim of starving cancer was envisioned (Folkman 1972, Cherrington et al. 2000). Excitingly, the anti-VEGF monoclonal antibody bevacizumab, which is sold under the trade name Avastin (Roche, Swiss and Genentech, Roche's U.S. Biotech Unit), was made available for clinical trials and showed clinical benefits for patients with cancer (Willett et al. 2004, Jain et al. 2006). In 2004, the use of bevacizumab in combination with chemotherapy was approved by the Food and Drug Administration (FDA) to treat metastatic colorectal cancer (Ferrara et al. 2004, Hurwitz et al. 2004, Saltz et al. 2008). Bevacizumab has also been approved as a treatment for other types of cancer, including metastatic kidney cancer. In the subsequent years, several tyrosine kinase inhibitors targeting VEGFRs and, therefore, also functioning as anti-angiogenic drugs were developed and clinically approved as cancer therapies. Axitinib, sunitinib, sorafenib, pazopanib, lenvatinib and cabozantinib are small-molecule tyrosine kinase inhibitors (TKIs) that target VEGFR2 (among other tyrosine kinases) and have been approved in different combinations as treatments for advanced kidney cancer. Despite the great initial excitement for anti-neo-angiogenic therapies, overall, both anti-VEGF and TKIs only benefit some patients for whom the drugs are recommended. Unfortunately, clinical responses are observed during a limited period until the development of resistance, which occurs in nearly all cases (Shojaei et al. 2012).

In normoxia, HIF $1 \alpha$ and HIF $2 \alpha$ are hydroxylated by the prolyl hydroxylase enzymes, ubiquitinated by the E3 ubiquitin ligase von Hippel-Lindau (VHL) and continually degraded via proteasomes (Fig. 1). When tissue environments are provided with low levels of oxygen, HIFs are no longer hydroxylated/degraded, becoming stable and promptly detectable. HIFs are transcription factors that control the de novo expression of dozens of genes involved in angiogenic signaling, cell migration and energy metabolism, among other pathways (Semenza et al. 1992, Maxwell et al. 1993, Wang et al. 1995, Iliopoulos et al. 1996, Epstein et al. 2001, Ivan et al. 2001, Jaakkola et al. 2001). Although the expression of several HIF target genes is regulated by both HIF1 $\alpha$ and HIF $2 \alpha$, HIF $1 \alpha$ - and HIF2 $\alpha$-exclusive gene targets have been identified and confer divergent and particular functions to each subunit (Rankin et al. 2007).

\section{Pseudohypoxia caused by mutations in VHL and other genes}

In addition to real hypoxia caused by accelerated clonal expansion, tumors also present oxygen-independent activation of HIFs due to genetic causes, a condition called pseudohypoxia (Bratslavsky et al. 2007). For example, the activation of HIF $2 \alpha$ caused by somatic inactivating mutations of the VHL gene is observed in nearly all ccRCCs (Gnarra et al. 1994, Herman et al. 1994). Based on the results from recent genomic studies, infrequent ccRCCs that express wild-type VHL carry recurrent hotspot mutations of transcription elongation factor $\mathrm{B}$ subunit 1 (TCEB1) that abolish Elongin C-VHL binding (Sato et al. 2013). VHL-null and TCEB1-mutated cells are unable to degrade HIF, leading to HIF $2 \alpha$ overexpression, which is considered the hallmark molecular feature of this cancer. Strengthening the role of HIF $2 \alpha$ as the main driver in ccRCC, knockdown of EPAS1 hinders growth of these tumors in animal model studies (Kondo et al. 2003, Zimmer et al. 2004).

Inherited mutations of $V H L$, which are also associated with the stabilization of HIFs, are the cause of VHL familial syndrome, which is characterized by blood-formed

Published by Bioscientifica Ltd. 


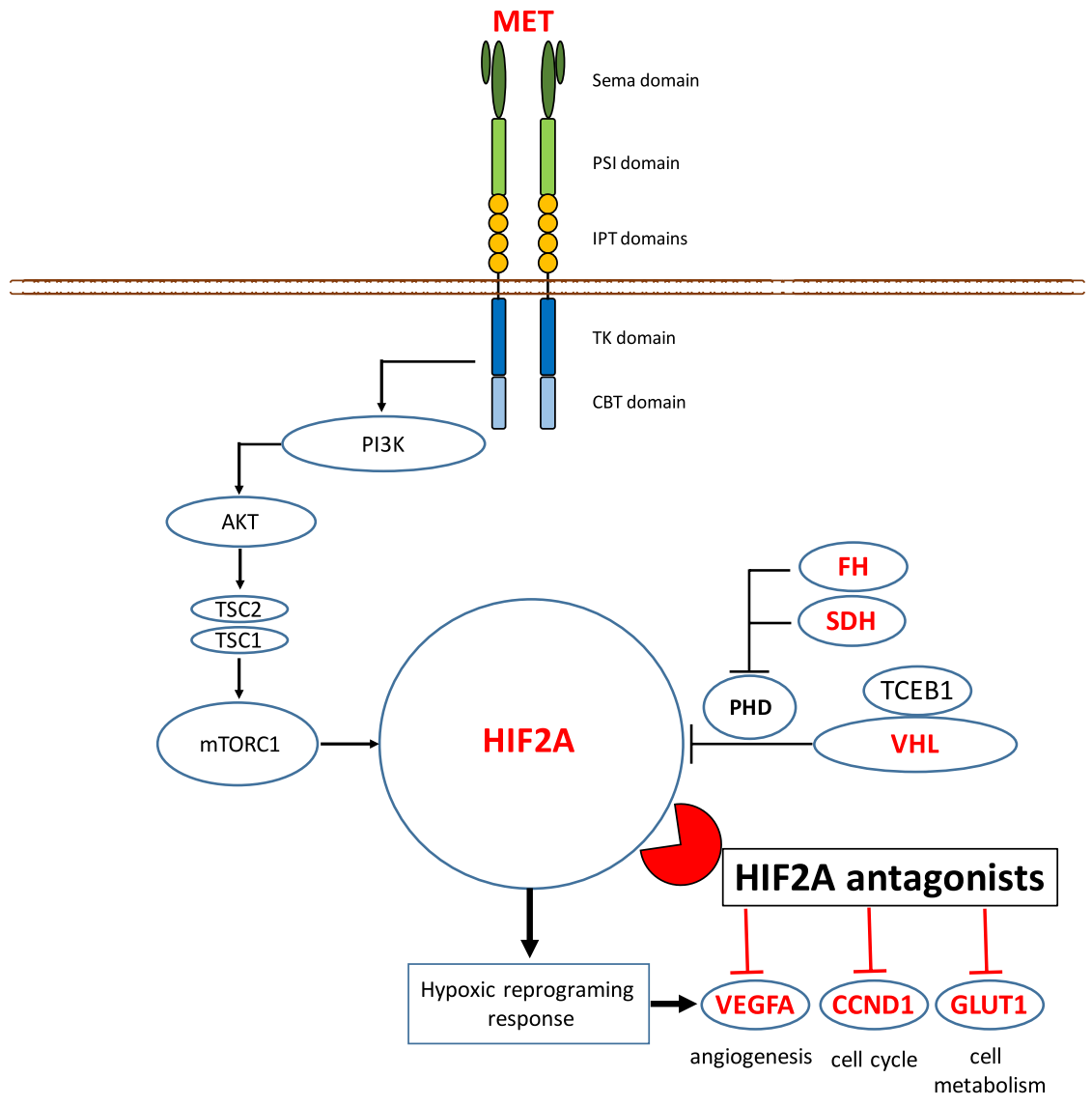

\section{Figure 1}

Activation of HIF $2 \alpha$ by frequent somatic mutations in the VHL gene is the hallmark of clear cell renal cell carcinoma (ccRCC). VHL is also a major PPGL susceptibility gene. In addition to $V H L$, mutations in $S D H x, F H$ and $M E T$ genes are also shared by both CCRCC and PPGLs. According to the results of tumor profiling studies, VHL-mutated cCRCCS and EPAS1 (HIF2 $\alpha$ )-mutated PPGLs present elevated levels of the HIF2 $\alpha$ target genes VEGFA, CCND1 and GLUT1, which are involved in angiogenesis, the cell cycle and cell metabolism. Newly developed HIF $\alpha$ antagonists downregulate the expression of these cancerrelated genes in ccRCC 786-0 VHL-null cell lines and in 786-0 xenograft tumors (Chen et al. 2016, Cho et al. 2016). A full color version of this figure is available at http://dx.doi.org/10.1530/ ERC-16-0479. tumors (hemangioblastomas), ccRCC and pancreatic neuroendocrine tumors, including pheochromocytomas (Latif et al. 1993). Notably, specific germline VHL mutations are associated with distinct clinical features, i.e., renal carcinoma alone, renal carcinoma associated with pheochromocytoma, and pheochromocytoma alone (Crossey et al. 1995, Zbar et al. 1996).

Pheochromocytomas and paragangliomas (PPGLs) are neural-crest-derived catecholamine-secreting neoplasias with remarkable genomic features. PPGLs are the most heritable tumors occurring in humans, and approximately $40 \%$ of these tumors are caused by a germline mutation in one of the more than fifteen different PPGL susceptibility genes reported to date (Jochmanová et al. 2013, Dahia 2014, Favier et al. 2015, Toledo et al. 2016). In addition to $V H L$, inactivating mutations in the SDHA/B/C/D genes, which encode the respective subunits of the succinate dehydrogenases, are also involved in PPGL predisposition and formation (Baysal et al. 2000, Niemann et al. 2000, Astuti et al. 2001, Milunsky et al. 2001, Burnichon et al. 2010). SDHs are enzymes involved in the tricarboxylic acid (TCA) cycle, and their genetic disruption triggers the accumulation of the TCA cycle metabolite succinate in the cytosol, where it inhibits prolyl hydroxylases
(PHDs), leading to HIF stabilization (Selak et al. 2005). Similar mechanisms of HIF stabilization are caused by rare mutations in the SDHAF2 gene, which encodes a HIF complex assembly protein (Bayley et al. 2010); the EGLN1 and EGLN2 genes, which encode the prolyl hydroxylase domain proteins responsible for signaling the VHLdependent degradation of HIF (Ladroue et al. 2008, Yang et al. 2015a); and the fumarate hydratase (FH) gene, which disrupts the Krebs cycle similar to SDH, leading to the stabilization of HIFs (Letouzé et al. 2013, Clark et al. 2014). Finally, non-heritable mutations in the EPAS1 gene are molecular drivers of PPGLs, as described below.

\section{Somatic or mosaic EPAS1 mutations occur in PPGLs}

Recently, mutations in the EPAS1 gene that encodes HIF2 $\alpha$ were independently discovered in PPGLs by two groups using candidate gene (Zhuang et al. 2012) and whole exome sequencing (Toledo et al. 2013) approaches. These discoveries represented the first reports of EPAS1 mutations in human cancers. PPGL cohorts have been screened worldwide for EPAS1 mutations, and to date, approximately forty PPGL-mutated cases have been

Published by Bioscientifica Ltd 
reported (Table 1 lists all PPGL EPAS1 mutations reported to date by Favier et al. 2012, Zhuang et al. 2012, CominoMendez et al. 2013, Lorenzo et al. 2013, Taieb et al. 2013, Toledo et al. 2013, Yang et al. 2013, Buffet et al. 2014, Crona et al. 2014, Toyoda et al. 2014, Welander et al. 2014a,b, Darr et al. 2016, Zhuang et al. 2016). Frequencies between $6 \%$ and $12 \%$ were observed, and thus EPAS1 mutations are one of the most frequent genetic defects occurring in PPGLs.

EPAS1 mutations are missense or compound missense mutations, with very rare cases of indels (5\%), and have been detected in patients with PPGL and different clinical features. Phenotypes included nonsyndromic PPGL, as well as patients with Pacak-Zhuang syndrome, which is characterized by polycythemia-PPGL with or without the co-occurrence of somatostatinoma (Table 1). All EPAS1 mutations are somatic or mosaic (Yang et al. 2015b), except for the germline variant F374Y (Lorenzo et al. 2013), which has been described as a rare polymorphism (NCBI dbSNP rs150797491). Although no genotypephenotype correlations have been described within PPGLs, a superposition of the PPGL-related and familial erythrocytosis type 4 (MIM \#611783)-related EPAS1 mutations has not been observed. Mutations occurring in both disorders are gain-of-function and occur within the oxygen-dependent degradation (ODD) domain; however, they affect near but distinct amino acids. PPGL mutations mainly affect amino acids 529-532, and erythrocytosis type 4 mutations occur exclusively within amino acids 533-540 (Percy et al. 2008a,b). A detailed assessment of the clinical features associated with EPAS1 mutations is beyond the scope of this manuscript and has been described elsewhere (Darr et al. 2016).

In contrast to the frequent EPAS1 mutations detected in PPGLs, these mutations are extremely rare in non-PPGL tumors. The visualization of genomic data from more than 31,000 tumor samples included in 145 projects of The Cancer Genome Atlas (TCGA) via CbioPortal for Cancer Genomics (www.cbioportal.org) reveals that a very small number of non-PPGL tumors carry EPAS1 mutations: only 221 samples were mutated $(0.007 \%$ ) (Supplementary Table 1 , see section on supplementary data given at the end of this article). These mutations occur throughout the gene and have no clear impact on tumorigenesis. Importantly, only three non-PPGL TCGA tumors harbor mutations between the L529 and Y532 PPGL mutation hotspot mutation residues (Supplementary Tables 1 and 2).
Supplementary Figures 1 and 2 show the mRNA expression levels and somatic mutation status of $V H L$ and EPAS1, respectively, among twenty-six TCGA projects. The highly frequent rates of $V H L$ mutations in ccRRC are associated with very low VHL mRNA levels. PPGLs also present decreased levels of the VHL mRNA, despite the presence of few mutations (Supplementary Fig. 1). In contrast, ccRCC and PPGLs present the highest and second highest levels of the EPAS1 mRNA among all tumor types (Supplementary Fig. 2). Notably, ccRCC samples with or without a VHL mutation present low levels of the VHL mRNA, consistent with the reported genetic and epigenetic inactivation of VHL in these tumors (Gnarra et al. 1994, Herman et al. 1994). Interestingly, all PPGLs harboring an EPAS1 mutation present elevated levels of the EPAS1 mRNA (Supplementary Fig. 3), whereas the EPAS1 gene is expressed at very high levels in ccRCC, despite the extremely rare incidence of mutations in this gene (Supplementary Fig. 4).

\section{PPGL EPAS1 mutations affect the ODD domain of HIF $2 \alpha$ and are oncogenic}

All bona fide EPAS1 mutations observed in PPGLs are located in the ODD domain in the vicinity of the proline-531 hydroxylation site of HIF $2 \alpha$. Two main hotspot mutations for EPAS1 have been observed: proline-531 itself and its neighboring residue alanine-530 (Fig. 2). Together, Ala530/Pro531 residues account for $62 \%$ of EPAS1 mutations described in PPGLs. Remarkably, up to $81 \%$ of all EPAS1 PPGL mutations are located between L529 and Y532 (Table 1).

Importantly, these mutations were carefully validated by studies conducted at three levels: (a) ectopic expression of HIF2 $\alpha$ mutants in VHL-wt and VHL-null cell lines (Zhuang et al. 2012, Toledo et al. 2013, Yang et al. 2013); (b) molecular characterization of gene expression and/or methylation signatures in the tumor (Favier et al. 2012, Zhuang et al. 2012, Toledo et al. 2013, Yang et al. 2013); and, finally, (c) analyses of the tumor growth capacity in xenografts generated from cell lines stably expressing HIF2 $\alpha$ mutants (Toledo et al. 2013). According to these studies, EPAS1 mutations are undoubtedly pathogenic, revealing a previously unrecognized mechanism of activation of the HIF $2 \alpha$ transcription program and tumor promotion via direct gain-of-function mutations in its gene. 


\section{Protein structure studies led to the development of HIF $2 \alpha$ inhibitors}

For many years, a number of transcription factors, including HIF $2 \alpha$, were considered undruggable, and pharmaceutical companies focused on the downstream pathway of HIFs, including VEGF and VEGFR2. In 2003, studies lead by Kevin Gardner and Rick Bruick from the University of Texas Southwestern Medical Center, Dallas, Texas, used nuclear magnetic resonance spectroscopy to define the structure of the HIF $2 \alpha$ protein and its binding with the aryl hydrocarbon receptor nuclear translocator (ARNT), also called HIF1B (Erbel et al. 2003). In 2009, the same group used crystallography to obtain structures of the heterodimer formed by HIF $2 \alpha$ PAS domains and ARNT. These analyses enabled the authors to refine the HIF $2 \alpha$ structure to a high quality and to discover a previously unrecognized cavity within the PAS-B domain. The HIF $2 \alpha$ cavity is located within the HIF $2 \alpha$ PAS-B domain and has large extensions measuring $7 \times 14 \times 15 \AA$, yielding a total volume of $290 \AA^{3}$ (Scheuermann et al. 2009, 2013, 2015, Rogers et al. 2013). This type of large cavity is extremely rare in proteins. This finding was therefore unexpected and very promising, as this cavity was likely capable of accommodating small molecules and being successfully targeted. Importantly, despite the great similarity in the protein sequences, this specific $290 \AA^{3}$ PAS-B cavity was exclusively observed in HIF $2 \alpha$, whereas the two other HIF $\alpha$ subunits (HIF $1 \alpha$ and HIF3 $\alpha$ ) present PAS-B cavities with distinctive features (Cardoso et al. 2012, Fala et al. 2015, Wu et al. 2015). Based on evidence from the protein structure, HIF2 $\alpha$ inhibitors were confirmed to be selective for HIF $2 \alpha$ and did not bind to HIF $1 \alpha$ and HIF $3 \alpha$ subunits (Scheuermann et al. 2009, 2013).

\section{Screening and selection of HIF $2 \alpha$ inhibitors}

Based on the structure of the HIF2 $\alpha$ :ARNT protein dimer, Peloton Therapeutics (Dallas, Texas) performed an extensive screening of small-molecule libraries and generated $130 \mathrm{HIF} 2 \alpha /$ inhibitor crystal structures. After analyzing the potency, selectivity and oral viability, compound PT2385 was chosen for clinical development. Compound PT2399 has been developed as a tool HIF2 $\alpha$ inhibitor used in in vivo studies and exhibits pharmacological properties that are equal to those of PT2385 (Scheuermann et al. 2013, 2015).

\section{PT2399 and PT2385 inhibitors downregulate the hypoxia transcriptional program and inhibit tumor growth in CCRCC models}

Based on expression analyses performed using qPCR and microarrays, the HIF $2 \alpha$ target genes VEGFA, cyclin D1 (CCDN1) and SLC2A1 (glucose transported protein type 1, GLUT1) are upregulated in PPGL tumors carrying an EPAS1 mutation. These findings were confirmed by ectopic transient or stable expression of HIF $2 \alpha$ mutants in human cell lines (Zhuang et al. 2012, Toledo et al. 2013, Yang et al. 2013), strengthening the gain-of-function character of these mutations. High levels of the mRNAs for these genes are also detected in VHL-mutated ccRCC cell lines or corresponding xenograft models. Treatment with PT2399 downregulates the expression of these genes and controls tumor growth induced by this transcriptional program both in vitro and in vivo (Chen et al. 2016, Cho et al. 2016, Wallace et al. 2016). Based on these results, PT2385 and PT2399 are expected to effectively control the hypoxia response gene signature in PPGLs. However, in addition to the classical hypoxia response genes, researchers must also consider EPAS1 mutations that upregulate the expression of the insulin-like growth factor 2 (IGF2) and c-MYC oncogenes, as well as genes involved with chromaffin differentiation and stemness, such as neuropeptide Y (NPY), NANOG, octamer-binding transcription factor 4 (OCT4), JAGGED2, keratin 19 (KRT19), SRY-box 9 (SOX9) and cadherin 2 (CDH2) (Toledo et al. 2013).

A phase 1 clinical trial (ClinicalTrials.gov ID NCT02293980) has evaluated the maximum tolerated dose of oral PT2385 alone and in combination with nivolumab, a PD-1 immune checkpoint inhibitor, and cabozantinib, an anti-angiogenic VEGFR2 inhibitor in patients with advanced ccRCC. Importantly, a prolonged response has been observed in at least one heavily treated, resistant patient with ccRCC (Chen et al. 2016). Importantly, the initial results of the combinations of HIF $2 \alpha$ inhibitors with immunotherapy have been recently reported and showed potential therapeutic synergism (Han et al. 2016).

\section{Prospective of testing HIF $2 \alpha$ inhibitors in PPGLs}

In a recent issue of Nature, two studies reported exciting results showing that the recently developed 


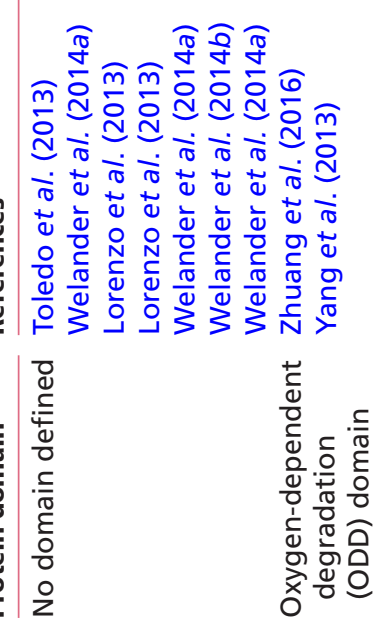

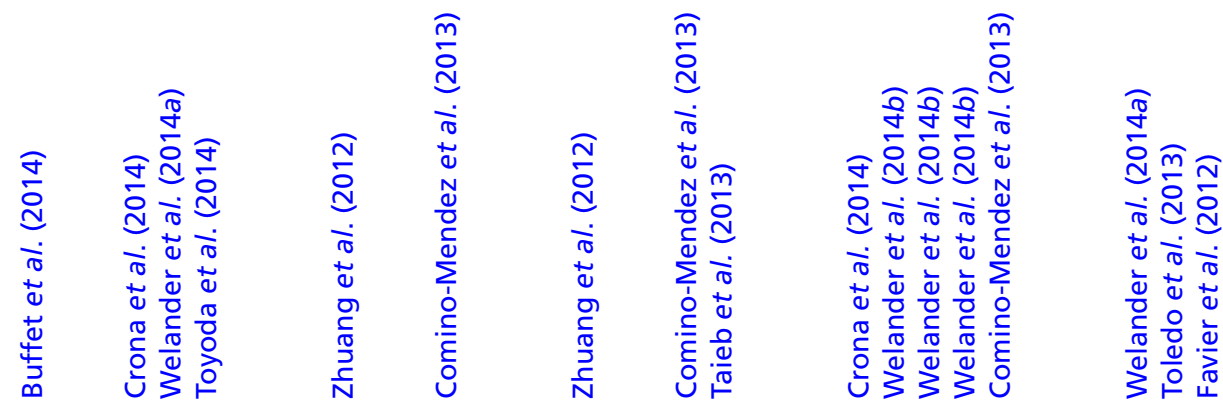
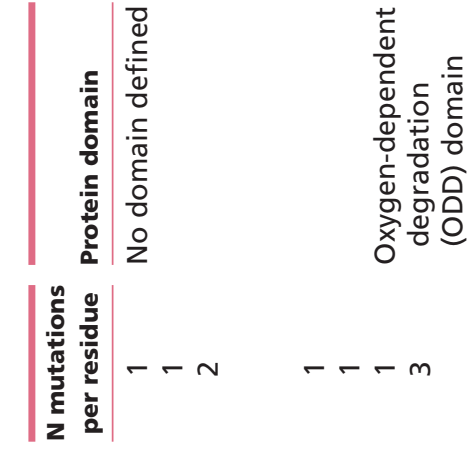

으

오

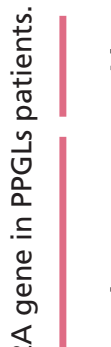

产

กิ

กิ

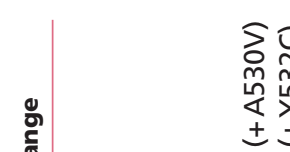

定柋

$\pm \pm$

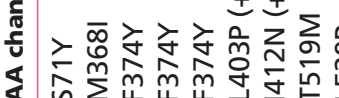

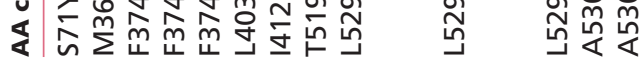

岁离

$\stackrel{2}{2}$

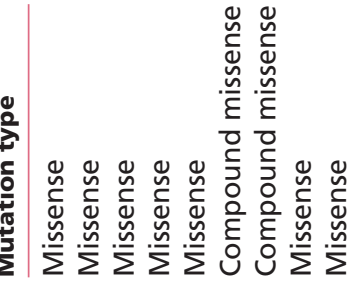

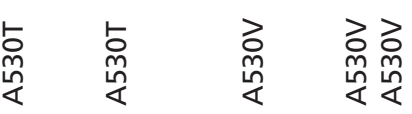

a
ò
+
t

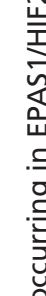

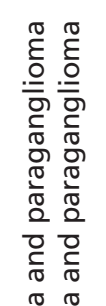

$\frac{\pi}{\varepsilon} \cdot \frac{\sigma}{\varepsilon}$

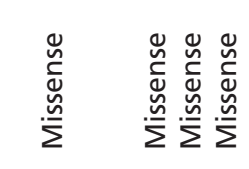

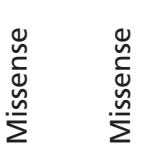

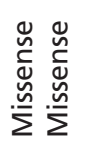

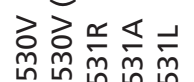

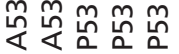

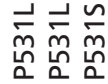

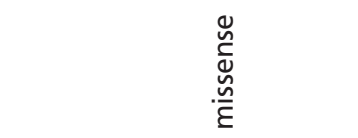

宛

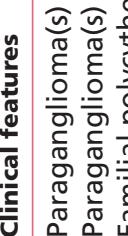

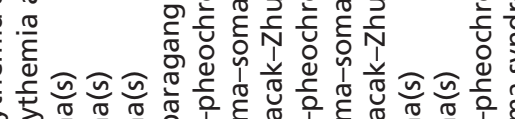

(9)

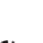

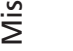

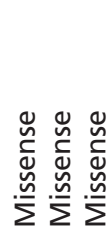

욜

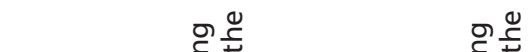



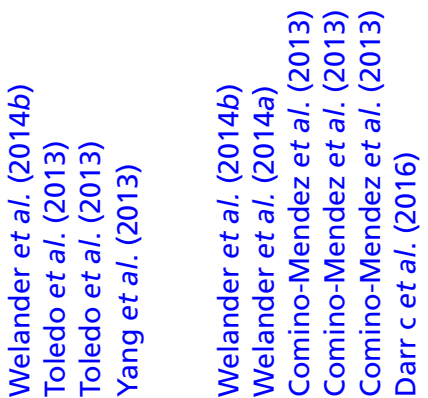

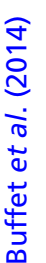

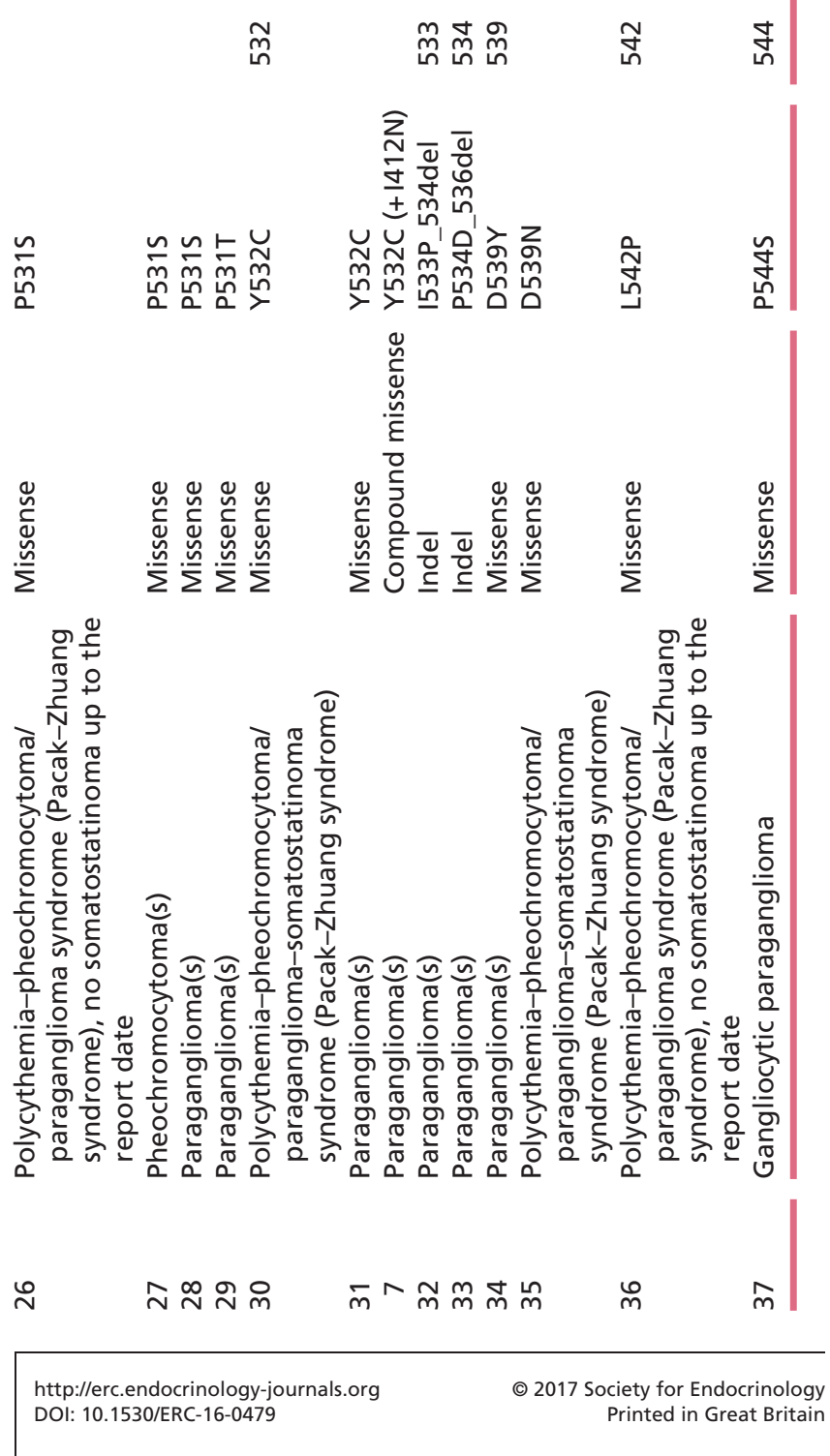

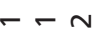

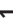

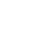

F
and PT2399 will be effective against the HIF2 $\alpha$ protein activated by EPAS1,VHL, SDHx and/or FH mutations in PPGL-derived chromatin cells.

Published by Bioscientifica Ltd. 


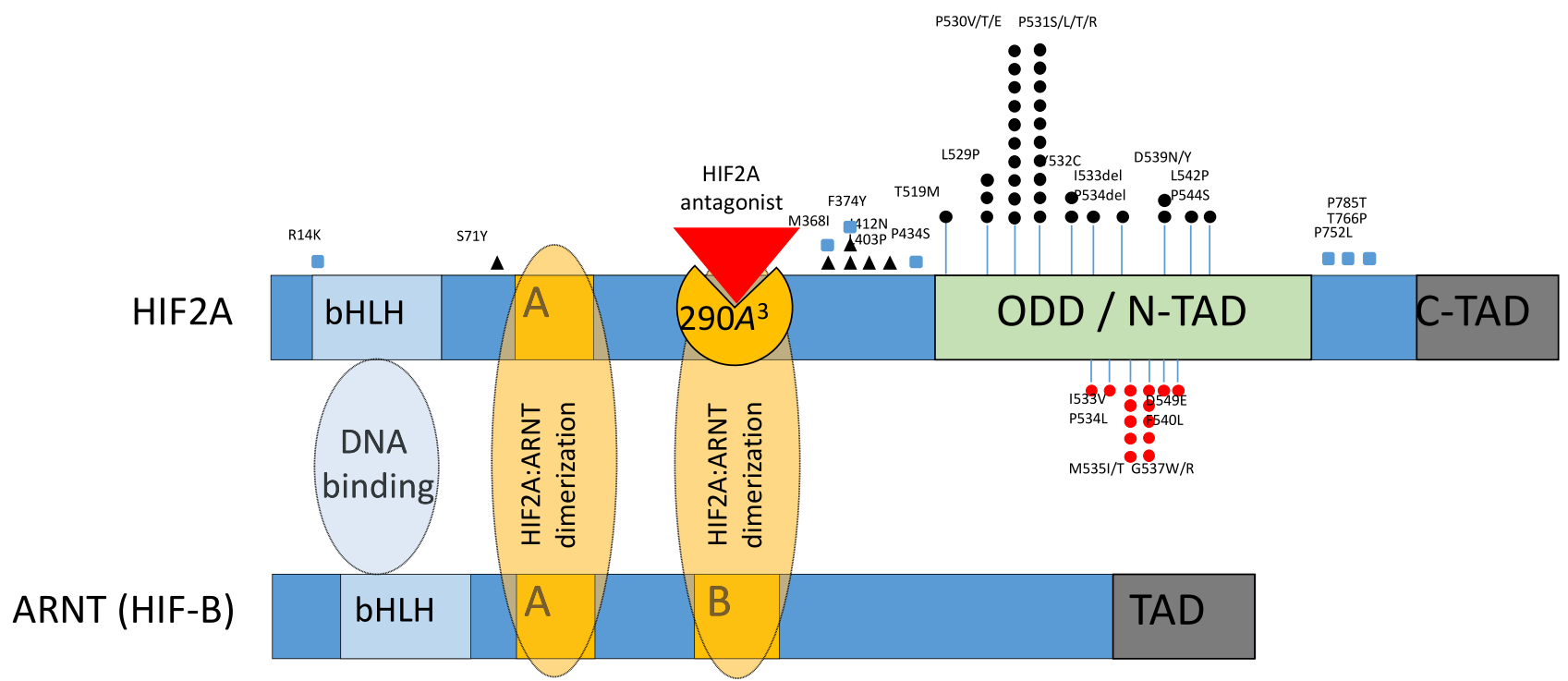

Figure 2

Mutations in the EPAS1 ${ }^{H 1 F 2 \alpha}$ gene occur in the ODD domain. Mutations reported in pheochromocytomas and paragangliomas are depicted in black, mutations reported in familial erythrocytosis (type 4, OMIM 611783) are depicted in red and common polymorphisms detected at a high frequency in healthy controls are depicted in blue. Circles illustrate mutations that have been shown or are likely to be pathogenic, triangles indicate variants with an unknown clinical significance (VUS) and squares indicate common polymorphisms. Structures, protein domains and regions of binding and dimerization of HIF2 $\alpha$ and ARNT (HIF-B) are shown. A: PAS (Per-ARNT-Sim) A domain; B: PAS (Per-ARNT-Sim) B domain. bHLH, basic helix-loop-helix domain; HIF2 $\alpha$ antagonist, PT2399 and PT2385 (peloton therapeutics); ODD, oxygen-dependent degradation domain; TAD, transactivation domain. A full color version of this figure is available at http://dx.doi.org/10.1530/ERC-16-0479.

\section{Clinical trials testing the efficacy of anti-angiogenic drugs in patients with PPGL}

The robust molecular findings implicating the disruption of the genes involved in the hypoxia response in PPGL tumorigenesis and case reports of prolonged responses in patients with advanced PPGL who were treated with antiangiogenic agents (Joshua et al. 2009) have spearheaded the initiation of further target therapeutic studies. Currently, several clinical trials are evaluating the efficacy of several VEGFR2 inhibitors in patients with advanced PPGL, including sunitinib (NCT00843037, NCT01371201), dovitinib (NCT01635907), axitinib (NCT01967576), lenvatinib (NCT03008369), cabozantinib (NCT02302833) and pazopanib (NCT01340794). Notably, the clinical study of cabozantinib is particularly interesting because, in addition to being the most potent VEGFR2 inhibitor $\left(\mathrm{IC}_{50}=0.035 \mathrm{nM}\right)$, it also strongly inhibits c-MET $\left(\mathrm{IC}_{50}=1.3 \mathrm{nM}\right)$, another oncogene that is frequently mutated in PPGLs (Castro-Vega et al. 2015, Toledo et al. 2016). Finally, the HIF2 $\alpha$ inhibitor PT2385 has now entered a phase II clinical trial (NCT03108066) evaluating its efficacy in advanced cancer patients carrying a $V H L$ germline mutation, and hopefully, patients with PPGL will also be recruited.
Supplementary data

This is linked to the online version of the paper at http://dx.doi.org/10.1530/ ERC-16-0479.

\section{Declaration of interest}

The authors declare that there is no conflict of interest that could be perceived as prejudicing the impartiality of this commentary.

\section{Funding}

This research did not receive any specific grant from any funding agency in the public, commercial or not-for-profit sector.

\section{References}

Astuti D, Douglas F, Lennard TW, Aligianis IA, Woodward ER, Evans DG, Eng C, Latif F \& Maher ER 2001 Germline SDHD mutation in familial phaeochromocytoma. Lancet 357 1181-1182. (doi:10.1016/ S0140-6736(00)04378-6)

Bayley JP, Kunst HP, Cascon A, Sampietro ML, Gaal J, Korpershoek E, Hinojar-Gutierrez A, Timmers HJ, Hoefsloot LH, Hermsen MA, et al. 2010 SDHAF2 mutations in familial and sporadic paraganglioma and phaeochromocytoma. Lancet Oncology 11 366-372. (doi:10.1016/ S1470-2045(10)70007-3)

Baysal BE, Ferrell RE, Willett-Brozick JE, Lawrence EC, Myssiorek D, Bosch A, van der Mey A, Taschner PE, Rubinstein WS,

Myers EN, et al. 2000 Mutations in SDHD, a mitochondrial complex
(C) 2017 Society for Endocrinology Printed in Great Britain
Published by Bioscientifica Ltd. 
II gene, in hereditary paraganglioma. Science $\mathbf{2 8 7} 848-851$. (doi:10.1126/science.287.5454.848)

Bertout JA, Patel SA \& Simon MC 2008 The impact of $\mathrm{O}_{2}$ availability on human cancer. Nature Reviews Cancer 8 967-975. (doi:10.1038/ nrc2540)

Bratslavsky G, Sudarshan S, Neckers L \& Linehan WM 2007 Pseudohypoxic pathways in renal cell carcinoma. Clinical Cancer Research 13 4667-4671. (doi:10.1158/1078-0432.CCR-06-2510)

Buffet A, Smati S, Mansuy L, Ménara M, Lebras M, Heymann MF, Simian C, Favier J, Murat A, Cariou B, et al. 2014 Mosaicism in HIF2Arelated polycythemia-paraganglioma syndrome. Journal of Clinical Endocrinology and Metabolism 99 369-373. (doi:10.1210/jc.2013-2600)

Burnichon N, Brière JJ, Libé R, Vescovo L, Rivière J, Tissier F, Jouanno E, Jeunemaitre X, Bénit P, Tzagoloff A, et al. 2010 SDHA is a tumor suppressor gene causing paraganglioma. Human Molecular Genetics 19 3011-3020. (doi:10.1093/hmg/ddq206)

Cardoso R, Love R, Nilsson CL, Bergqvist S, Nowlin D, Yan J, Liu KK, Zhu J, Chen P, Deng YL, et al. 2012 Identification of Cys255 in HIF- $1 \alpha$ as a novel site for development of covalent inhibitors of HIF-1 $\alpha /$ ARNT PasB domain protein-protein interaction. Protein Science 21 1885-1896. (doi:10.1002/pro.2172)

Castro-Vega LJ, Letouzé E, Burnichon N, Buffet A, Disderot PH, Khalifa E, Loriot C, Elarouci N, Morin A, Menara M, et al. 2015 Multi-omics analysis defines core genomic alterations in pheochromocytomas and paragangliomas. Nature Communications 6 6044. (doi:10.1038/ncomms7044)

Chen W, Hill H, Christie A, Kim MS, Holloman E, Pavia-Jimenez A, Homayoun F, Ma Y, Patel N, Yell P, et al. 2016 Targeting renal cell carcinoma with a HIF-2 antagonist. Nature 539 112-117. (doi:10.1038/nature19796)

Cherrington JM, Strawn LM \& Shawver LK 2000 New paradigms for the treatment of cancer: the role of anti-angiogenesis agents. Advances in Cancer Research 79 1-38. (doi:10.1016/s0065-230x(00)79001-4)

Cho H, Du X, Rizzi JP, Liberzon E, Chakraborty AA, Gao W, Carvo I, Signoretti S, Bruick R, Josey JA, et al. 2016 On-target efficacy of a HIF2 $\alpha$ antagonist in preclinical kidney cancer models. Nature 539 107-111. (doi:10.1038/nature19795).

Clark GR, Sciacovelli M, Gaude E, Walsh DM, Kirby G, Simpson MA, Trembath RC, Berg JN, Woodward ER, Kinning E, et al. 2014 Germline FH mutations presenting with pheochromocytoma. Journal of Clinical Endocrinology and Metabolism 99 2046-2050. (doi:10.1210/ jc.2014-1659)

Comino-Méndez I, de Cubas AA, Bernal C, Álvarez-Escolá C, Sánchez-Malo C, Ramírez-Tortosa CL, Pedrinaci S, Rapizzi E, Ercolino T, Bernini G, et al. 2013 Tumoral EPAS1 (HIF2A) mutations explain sporadic pheochromocytoma and paraganglioma in the absence of erythrocytosis. Human Molecular Genetics 22 2169-2176. (doi:10.1093/hmg/ddt069)

Crona J, Nordling M, Maharjan R, Granberg D, Stålberg P, Hellman P \& Björklund P 2014 Integrative genetic characterization and phenotype correlations in pheochromocytoma and paraganglioma tumours. PLOS ONE 9 86756. (doi:10.1371/journal.pone.0086756)

Crossey PA, Eng C, Ginalska-Malinowska M, Lennard TW, Wheeler DC, Ponder BA \& Maher ER 1995 Molecular genetic diagnosis of von Hippel-Lindau disease in familial phaeochromocytoma. Journal of Medical Genetics 32 885-886. (doi:10.1136/jmg.32.11.885)

Dahia PL 2014 Pheochromocytoma and paraganglioma pathogenesis: learning from genetic heterogeneity. Nature Reviews Cancer 14 108-119. (doi:10.1038/nrc3648)

Dahia PL, Ross KN, Wright ME, Hayashida CY, Santagata S, Barontini M Kung AL, Sanso G, Powers JF, Tischler AS, et al. 2005 A HIF1alpha regulatory loop links hypoxia and mitochondrial signals in pheochromocytomas. PLoS Genetics 1 72-80.

Därr R, Nambuba J, Del Rivero J, Janssen I, Merino M, Todorovic M, Balint B, Jochmanova I, Prchal JT, Lechan R, et al. 2016 Novel insights into the polycythemia-paraganglioma-somatostatinoma http://erc.endocrinology-journals.org

DOI: $10.1530 /$ ERC-16-0479
(C) 2017 Society for Endocrinology Printed in Great Britain syndrome. Endocrine-Related Cancer 23 899-908. (doi:10.1530/ ERC-16-0231)

Epstein AC, Gleadle JM, McNeill LA, Hewitson KS, O’Rourke J, Mole DR, Mukherji M, Metzen E, Wilson MI, Dhanda A, et al. 2001 C. elegans EGL-9 and mammalian homologs define a family of dioxygenases that regulate HIF by prolyl hydroxylation. Cell 107 43-54. (doi:10.1016/S0092-8674(01)00507-4)

Erbel PJ, Card PB, Karakuzu O, Bruick RK \& Gardner KH 2003 Structural basis for PAS domain heterodimerization in the basic helix-loophelix-PAS transcription factor hypoxia-inducible factor. PNAS $\mathbf{1 0 0}$ 15504-15509. (doi:10.1073/pnas.2533374100)

Fala AM, Oliveira JF, Adamoski D, Aricetti JA, Dias MM, Dias MV, Sforça ML, Lopes-de-Oliveira PS, Rocco SA, Caldana C, et al. 2015 Unsaturated fatty acids as high-affinity ligands of the C-terminal Per-ARNT-Sim domain from the Hypoxia-inducible factor $3 \alpha$. Science Reports 5 12698. (doi:10.1038/srep12698)

Favier J, Buffet A \& Gimenez-Roqueplo AP 2012 HIF2A mutations in paraganglioma with polycythemia. New England Journal of Medicine 367 2161. (doi:10.1056/NEJMc1211953)

Favier J, Amar L \& Gimenez-Roqueplo AP 2015 Paraganglioma and phaeochromocytoma: from genetics to personalized medicine. Nature Reviews Endocrinology 11 101-111. (doi:10.1038/nrendo.2014.188)

Ferrara N, Hillan KJ, Gerber HP \& Novotny W 2004 Discovery and development of bevacizumab, an anti-VEGF antibody for treating cancer. Nature Reviews Drug Discovery 3 391-400. (doi:10.1038/nrd1381)

Fliedner SM, Shankavaram U, Marzouca G, Elkahloun A, Jochmanova I, Daerr R, Linehan WM, Timmers H, Tischler AS, Papaspyrou K, et al. 2016 Hypoxia-inducible factor $2 \alpha$ mutation-related paragangliomas classify as discrete pseudohypoxic subcluster. Neoplasia 18 567-576. (doi:10.1016/j.neo.2016.07.008)

Folkman J 1971 Tumor angiogenesis: therapeutic implications New England Journal of Medicine 285 1182-1186. (doi:10.1056/ NEJM197111182852108)

Folkman J 1972 Anti-angiogenesis: new concept for therapy of solid tumors. Annals of Surgery 175 409-416. (doi:10.1097/00000658197203000-00014)

Folkman J 1995 Angiogenesis in cancer, vascular, rheumatoid and other disease. Nature Medicine 1 27-31. (doi:10.1038/nm0195-27)

Folkman J 2007 Angiogenesis: an organizing principle for drug discovery? Nature Reviews Drug Discovery 6 273-286. (doi:10.1038/nrd2115)

Gnarra JR, Tory K, Weng Y, Schmidt L, Wei MH, Li H, Latif F, Liu S, Chen F, Duh FM, et al. 1994 Mutations of the VHL tumour suppressor gene in renal carcinoma. Nature Genetics 7 85-90. (doi:10.1038/ng0594-85)

Han G, Stevens C, Cao Z, Xie S, Maddie M, Goggin B, Wallace E, Josey J \& Wong TW 2016 Abstract 4022: PT2385, a novel HIF-2 $\alpha$ antagonist, combines with checkpoint inhibitor antibodies to inhibit tumor growth in preclinical models by modulating myeloid cells and enhancing T cell infiltration. Cancer Research 76 (14 Supplement) abstract 4022. (doi:10.1158/1538-7445.AM2016-4022)

Hanahan D \& Folkman J 1996 Patterns and emerging mechanisms of the angiogenic switch during tumorigenesis. Cell 86 353-364. (doi:10.1016/S0092-8674(00)80108-7)

Hanahan D \& Weinberg RA 2011 Hallmarks of cancer: the next generation. Cell 144 646-674. (doi:10.1016/j.cell.2011.02.013)

Herman JG, Latif F, Weng Y, Lerman MI, Zbar B, Liu S, Samid D, Duan DS, Gnarra JR, Linehan WM, et al. 1994 Silencing of the VHL tumorsuppressor gene by DNA methylation in renal carcinoma. PNAS 91 9700-9704. (doi:10.1073/pnas.91.21.9700)

Hurwitz H, Fehrenbacher L, Novotny W, Cartwright T, Hainsworth J, Heim W, Berlin J, Baron A, Griffing S, Holmgren E, et al. 2004 Bevacizumab plus irinotecan, fluorouracil, and leucovorin formetastatic colorectal cancer. New England Journal of Medicine $\mathbf{3 5 0}$ 2335-2342. (doi:10.1056/NEJMoa032691)

Iliopoulos O, Levy AP, Jiang C, Kaelin WG Jr \& Goldberg MA 1996 Negative regulation of hypoxia-inducible genes by the von Hippel-

Published by Bioscientifica Ltd. 
Lindau protein. PNAS 93 10595-10599. (doi:10.1073/ pnas.93.20.10595)

Ivan M, Kondo K, Yang H, Kim W, Valiando J, Ohh M, Salic A, Asara JM, Lane WS \& Kaelin WG Jr 2001 HIFalph a targeted for VHL-mediated destruction by proline hydroxylation: implications for $\mathrm{O}_{2}$ sensing. Science 292 464-468. (doi:10.1126/science.1059817)

Jaakkola P, Mole DR, Tian YM, Wilson MI, Gielbert J, Gaskell SJ, von Kriegsheim A, Hebestreit HF, Mukherji M, Schofield CJ, et al. 2001 Targeting of HIF-alpha to the von Hippel-Lindau ubiquitylation complex by $\mathrm{O}_{2}$-regulated prolyl hydroxylation. Science 292 468-472. (doi:10.1126/science.1059796)

Jain RK, Duda DG, Clark JW \& Loeffler JS 2006 Lessons from phase III clinical trials on anti-VEGF therapy for cancer. Nature Clinical Practice Oncology 3 24-40. (doi:10.1038/ncponc0403)

Jochmanová I, Yang C, Zhuang Z \& Pacak K 2013 Hypoxia-inducible factor signaling in pheochromocytoma: turning the rudder in the right direction. Journal of the National Cancer Institute $\mathbf{1 0 5}$ 1270-1283. (doi:10.1093/jnci/djt201)

Joshua AM, Ezzat S, Asa SL, Evans A, Broom R, Freeman M \& Knox JJ 2009 Rationale and evidence for sunitinib in the treatment of malignant paraganglioma/pheochromocytoma. Journal of Clinical Endocrinology and Metabolism 94 5-9. (doi:10.1210/jc.2008-1836)

Kaelin WG Jr 2008 The von Hippel-Lindau tumour suppressor protein: $\mathrm{O}_{2}$ sensing and cancer. Nature Reviews Cancer 8 865-873. (doi:10.1038/nrc2502)

Kaelin WG Jr, Ratcliffe PJ \& Semenza GL 2016 Pathways for oxygen regulation and homeostasis: the 2016 Albert Lasker basic medical research award. JAMA 316 1252-1253. (doi:10.1001/ jama.2016.12386)

Kondo K, Kim WY, Lechpammer M \& Kaelin WG Jr 2003 Inhibition of HIF2alpha is sufficient to suppress pVHL-defective tumor growth. PLoS Biology 1 83. (doi:10.1371/journal.pbio.0000083)

Ladroue C, Carcenac R, Leporrier M, Gad S, Le Hello C, Galateau-Salle F, Feunteun J, Pouysségur J, Richard S \& Gardie B 2008 PHD2 mutation and congenital erythrocytosis with paraganglioma. New England Journal of Medicine 359 2685-2692. (doi:10.1056/NEJMoa0806277)

Latif F, Tory K, Gnarra J, Yao M, Duh FM, Orcutt ML, Stackhouse T, Kuzmin I, Modi W, Geil L, et al. 1993 Identification of the von Hippel-Lindau disease tumor suppressor gene. Science 260 1317-1320. (doi:10.1126/science.8493574)

Letouzé E, Martinelli C, Loriot C, Burnichon N, Abermil N, Ottolenghi C, Janin M, Menara M, Nguyen AT \& Benit P 2013 SDH mutations establish a hypermethylator phenotype in paraganglioma. Cancer Cell 23 739-752. (doi:10.1016/j.ccr.2013.04.018)

Lorenzo FR, Yang C, Ng Tang Fui M, Vankayalapati H, Zhuang Z Huynh T, Grossmann M, Pacak K \& Prchal JT 2013 A novel EPAS1/ HIF2A germline mutation in a congenital polycythemia with paraganglioma. Journal of Molecular Medicine 91 507-512. (doi:10.1007/s00109-012-0967-z)

Maxwell PH, Pugh CW \& Ratcliffe PJ 1993 Inducible operation of the erythropoietin 3' enhancer in multiple cell lines: evidence for a widespread oxygen-sensing mechanism. PNAS 90 2423-2427. (doi:10.1073/pnas.90.6.2423)

Milunsky JM, Maher TA, Michels VV \& Milunsky A 2001 Novel mutations and the emergence of a common mutation in the SDHD gene causing familial paraganglioma. American Journal of Medical Genetics 100 311-314. (doi:10.1002/ajmg.1270)

Niemann S \& Müller U 2000 Mutations in SDHC cause autosomal dominant paraganglioma, type 3. Nature Genetics 26 268-270. (doi:10.1038/81551)

Percy MJ, Beer PA, Campbell G, Dekker AW, Green AR, Oscier D, Rainey MG, van Wijk R, Wood M, Lappin TR, et al. 2008a Novel exon 12 mutations in the HIF2A gene associated with erythrocytosis. Blood 111 5400-5402. (doi:10.1182/blood-2008-02-137703)

Percy MJ, Furlow PW, Lucas GS, Li X, Lappin TR, McMullin MF \& Lee FS $2008 b$ A gain-of-function mutation in the HIF2A gene in familial erythrocytosis. New England Journal of Medicine 358 162-168. (doi:10.1056/NEJMoa073123)

Rankin EB, Biju MP, Liu Q, Unger TL, Rha J, Johnson RS, Simon MC, Keith B \& Haase VH 2007 Hypoxia-inducible factor-2 (HIF-2) regulates hepatic erythropoietin in vivo. Journal of Clinical Investigation 117 1068-1077. (doi:10.1172/JCI30117)

Rogers JL, Bayeh L, Scheuermann TH, Longgood J, Key J, Naidoo J, Melito L, Shokri C, Frantz DE, Bruick RK, et al. 2013 Development of inhibitors of the PAS-B domain of the HIF- $2 \alpha$ transcription factor. Journal of Medicinal Chemistry 56 1739-1747. (doi:10.1021/ jm301847z)

Saltz LB, Clarke S, Díaz-Rubio E, Scheithauer W, Figer A, Wong R, Koski S, Lichinitser M, Yang TS, Rivera F, et al. 2008 Bevacizumab in combination with oxaliplatin-based chemotherapy as first-line therapy in metastatic colorectal cancer: a randomized phase III study. Journal of Clinical Oncology 26 2013-2019. (doi:10.1200/ JCO.2007.14.9930)

Sato Y, Yoshizato T, Shiraishi Y, Maekawa S, Okuno Y, Kamura T, Shimamura T, Sato-Otsubo A, Nagae G, Suzuki H, et al. 2013 Integrated molecular analysis of clear-cell renal cell carcinoma. Nature Genetics 45 860-867. (doi:10.1038/ng.2699)

Scheuermann TH, Tomchick DR, Machius M, Guo Y, Bruick RK \& Gardner KH 2009 Artificial ligand binding within the HIF2alpha PAS-B domain of the HIF2 transcription factor. PNAS 106 450-455. (doi:10.1073/pnas.0808092106)

Scheuermann TH, Li Q, Ma HW, Key J, Zhang L, Chen R, Garcia JA, Naidoo J, Longgood J, Frantz DE, et al. 2013 Allosteric inhibition of hypoxia inducible factor-2 with small molecules. Nature Chemical Biology 9 271-276. (doi:10.1038/nchembio.1185)

Scheuermann TH, Stroud D, Sleet CE, Bayeh L, Shokri C, Wang H, Caldwell CG, Longgood J, MacMillan JB, Bruick RK, et al. 2015 Isoform-selective and stereoselective inhibition of hypoxia inducible factor-2. Journal of Medicinal Chemistry 58 5930-5941. (doi:10.1021/ acs.jmedchem.5b00529)

Selak MA, Armour SM, MacKenzie ED, Boulahbel H, Watson DG, Mansfield KD, Pan Y, Simon MC, Thompson CB \& Gottlieb E 2015 Succinate links TCA cycle dysfunction tooncogenesis by inhibiting HIF-alpha prolyl hydroxylase. Cancer Cell 7 77-85.

Semenza GL \& Wang GL 1992 A nuclear factor induced by hypoxia via de novo protein synthesis binds to the human erythropoietin gene enhancer at a site required for transcriptional activation. Molecular and Cellular Biology 12 5447-5454. (doi:10.1128/MCB.12.12.5447)

Shojaei F 2012 Anti-angiogenesis therapy in cancer: current challenges and future perspectives. Cancer Letters 320 130-137. (doi:10.1016/j. canlet.2012.03.008)

Taïeb D, Yang C, Delenne B, Zhuang Z, Barlier A, Sebag F \& Pacak K 2013 First report of bilateral pheochromocytoma in the clinical spectrum of HIF2A-related polycythemia-paraganglioma syndrome. Journal of Clinical Endocrinology and Metabolism 98 908-913. (doi:10.1530/ERC-13-0101)

Toledo RA, Qin Y, Srikantan S, Morales NP, Li Q, Deng Y, Kim SW, Pereira MA, Toledo SP, Su X, et al. 2013 In vivo and in vitro oncogenic effects of HIF2A mutations in pheochromocytomas and paragangliomas. Endocrine-Related Cancer 20 349-359. (doi:10.1530/ ERC-13-0101)

Toledo RA, Qin Y, Cheng ZM, Gao Q, Iwata S, Silva GM, Prasad ML, Ocal IT, Rao S, Aronin N, et al. 2016 Recurrent mutations of chromatin-remodeling genes and kinase receptors in pheochromocytomas and paragangliomas. Clinical Cancer Research 22 2301-2310. (doi:10.1158/1078-0432.CCR-15-1841)

Toyoda H, Hirayama J, Sugimoto Y, Uchida K, Ohishi K, Hirayama M \& Komada Y 2014 Polycythemia and paraganglioma with a novel somatic HIF2A mutation in a male. Pediatrics 133 1787-1791. (doi:10.1542/peds.2013-2419)

Wallace EM, Rizzi JP, Han G, Wehn PM, Cao Z, Du X, Cheng T, Czerwinski RM, Dixon DD, Goggin BS, et al. 2016 A small-molecule http://erc.endocrinology-journals.org

DOI: $10.1530 /$ ERC-16-0479
(C) 2017 Society for Endocrinology Printed in Great Britain 
antagonist of HIF2 $\alpha$ is efficacious in preclinical models of renal cell carcinoma. Cancer Research 76 5491-5500. (doi:10.1158/0008-5472. CAN-16-0473)

Wang GL, Jiang BH, Rue EA \& Semenza GL 1995 Hypoxia-inducible factor 1 is a basic-helix-loop-helix-PAS heterodimer regulated by cellular $\mathrm{O}_{2}$ tension. PNAS 92 5510-5514. (doi:10.1073/ pnas.92.12.5510)

Weidner N, Semple JP, Welch WR \& Folkman J 1991 Tumor angiogenesis and metastasis-correlation in invasive breast carcinoma. New England Journal of Medicine 324 1-8. (doi:10.1056/NEJM199101033240101)

Welander J, Andreasson A, Brauckhoff M, Bäckdahl M, Larsson C, Gimm O \& Söderkvist P 2014a Frequent EPAS1/HIF2 $\alpha$ exons 9 and 12 mutations in non-familial pheochromocytoma. Endocrine-Related Cancer 21 495-504. (doi:10.1530/ERC-13-0384)

Welander J, Andreasson A, Juhlin CC, Wiseman RW, Bäckdahl M, Höög A, Larsson C, Gimm O \& Söderkvist P 2014b Rare germline mutations identified by targeted next-generation sequencing of susceptibility genes in pheochromocytoma and paraganglioma. Journal of Clinical Endocrinology and Metabolism 99 1352-1360. (doi:10.1210/jc.2013-4375)

Willett CG, Boucher Y, di Tomaso E, Duda DG, Munn LL, Tong RT, Chung DC, Sahani DV, Kalva SP, Kozin SV, et al. 2004 Direct evidence that the VEGF-specific antibody bevacizumab has antivascular effects in human rectal cancer. Nature Medicine 10 145-147. (doi:10.1038/nm988)

Wu D, Potluri N, Lu J, Kim Y \& Rastinejad F 2015 Structural integration in hypoxia-inducible factors. Nature 524 303-308. (doi:10.1038/ nature14883)

Yang C, Sun MG, Matro J, Huynh TT, Rahimpour S, Prchal JT, Lechan R, Lonser R, Pacak K \& Zhuang Z 2013 Novel HIF2A mutations disrupt oxygen sensing, leading to polycythemia, paragangliomas, and somatostatinomas. Blood 121 2563-2566. (doi:10.1182/blood-201210-460972)

Yang C, Zhuang Z, Fliedner SM, Shankavaram U, Sun MG, Bullova P, Zhu R, Elkahloun AG, Kourlas PJ, Merino M, et al. 2015a Germ-line PHD1 and PHD2 mutations detected in patients with pheochromocytoma/paraganglioma-polycythemia. Journal of Molecular Medicine 93 93-104. (doi:10.1007/s00109-014-1205-7)

Yang C, Hong CS, Prchal JT, Balint MT, Pacak K \& Zhuang Z 2015b Somatic mosaicism of EPAS1 mutations in the syndrome of paraganglioma and somatostatinoma associated with polycythemia. Human Genome Variation 2 15053. (doi:10.1038/hgv.2015.53)

Zbar B, Kishida T, Chen F, Schmidt L, Maher ER, Richards FM, Crossey PA, Webster AR, Affara NA, Ferguson-Smith MA, et al. 1996 Germline mutations in the Von Hippel-Lindau disease (VHL) gene in families from North America, Europe, and Japan. Human Mutation 8 348-357. (doi:10.1002/(SICI)1098-1004(1996)8:4<348::AIDHUMU8>3.0.CO;2-3)

Zhuang Z, Yang C, Lorenzo F, Merino M, Fojo T, Kebebew E, Popovic V, Stratakis CA, Prchal JT \& Pacak K 2012 Somatic HIF2A gain-offunction mutations in paraganglioma with polycythemia. New England Journal of Medicine 367 922-930. (doi:10.1056/ NEJMoa1205119)

Zhuang Z, Yang C, Ryska A, Ji Y, Hou Y, Graybill SD, Bullova P, Lubensky IA, Klöppel G \& Pacak K 2016 HIF2A gain-of-function mutations detected in duodenal gangliocytic paraganglioma. Endocrine-Related Cancer 23 13-26. (doi:10.1530/ERC-16-0148)

Zimmer M, Doucette D, Siddiqui N \& Iliopoulos O 2004 Inhibition of hypoxia-inducible factor is sufficient for growth suppression of VHL-/- tumors. Molecular Cancer Research 2 89-95.

Received in final form 19 June 2017

Accepted 23 June 2017

Accepted Preprint published online 30 June 2017
(C) 2017 Society for Endocrinology Printed in Great Britain
Published by Bioscientifica Ltd 